\title{
Penyuntikan Tiga Kali Ekstrak Pituitari Selama Induk Sapi Bali Bunting Meningkatkan Bobot Lahir dan Produksi Air Susu
}

\author{
(THREE TIMES INJECTIONS OF PITUITARY EXTRACT DURING THE PREGNANCY \\ PERIOD OF BALI COWS INCREASING BIRTH WEIGHT AND MILK PRODUCTION)
}

\author{
Wilmientje Marlene Nalley, Thomas Mata Hine, Petrus Kune \\ Fakultas Peternakan, Universitas Nusa Cendana \\ Jl. Adi Sucipto, Penfui, Kec. Kelapa Lima, Kota Kupang \\ Provinsi Nusa Tenggara Timur, Indonesia, 85001 \\ Email: nalleywm@yahoo.co.id
}

\begin{abstract}
ABSTRAK
Penelitian ini bertujuan untuk menguji efek pemberian ekstrak pituitari (EP) terhadap produktivitas induk sapi bali bunting. Sebanyak 12 ekor sapi bali bunting 2,5 bulan dibagi ke dalam empat perlakuan yaitu: tanpa injeksi EP (P0, kontrol), injeksi EP satu kali pada umur kebuntingan 2,5 bulan (P1), injeksi EP dua kali pada umur kebuntingan 2,5 dan 5,0 bulan (P2), dan injeksi EP tiga kali pada umur kebuntingan 2,5, 5,0 dan 7,5 bulan (P3). Dosis EP yang diberikan adalah $20 \mathrm{mg} / \mathrm{kg}$ bobot badan. Parameter yang diamati adalah jumlah dan morfologi corpus luteum (CL), bobot lahir anak, dan produksi susu induk. Data yang diperoleh dianalisis dengan uji sidik ragam dan dilanjutkan dengan Uji jarak berganda Duncan. Hasil penelitian menunjukkan bahwa injeksi EP tidak memengaruhi $(\mathrm{P}>0,05)$ jumlah dan morfologi CL. Bobot lahir anak $(19,87 \mathrm{~kg})$ dan produksi susu induk harian $(1.707,18 \mathrm{~mL})$ tertinggi $(\mathrm{P}<0,05)$ dihasilkan oleh sapi bali yang diinjeksi EP tiga kali. Penelitian ini menyimpulkan bahwa penyuntikan EP tiga kali efektif meningkatkan bobot lahir anak dan produksi susu induk sapi bali.
\end{abstract}

Kata-kata kunci: ekstrak pituitari; bobot lahir; produksi susu; sapi bali bunting

\begin{abstract}
This study aimed to examine the effect of pituitary extract (EP) on the productivity of pregnant cow. Twelve 2.5-month-old pregnant cow were divided into four groups: no EP injection (P0, control), one-time EP injection at 2.5 months of gestation (P1), EP injection twice at gestational age 2.5 and 5.0 months (P2), and three times EP injection at gestational age 2.5, 5.0 and 7.5 months (P3). The EP dose was $20 \mathrm{mg} / \mathrm{kg}$ body weight. The parameters observed were the amount and morphology of the corpus luteum (CL), birth weight of calf, and milk production. The data obtained were analyzed by analysis of variance (ANOVA) and continued with Duncan Test. The results showed that EP injection did not affect $(\mathrm{P}>0.05)$ the number and morphology of CL. The highest calf birth weights $(19.87 \mathrm{~kg})$ and daily milk production $(1.707 .18 \mathrm{~mL})$ were produced by bali cows who were injected with EP three times $(\mathrm{P}<0.05)$. This study concluded that the injection of three times EP effectively increased the birth weight of calf and milk production in bali cows.
\end{abstract}

Keywords: pituitary extract; calf birth weights; milk production; pregnant Bali cow

\section{PENDAHULUAN}

Sapi bali termasuk salah satu bangsa ternak yang perlu dilindungi dan dipertahankan karena memiliki beberapa keunggulan seperti kemampuan hidup dengan pakan kualitas rendah dan tekanan iklim setempat, serta lebih tahan terhadap penyakit dan parasit lokal (FAO,
2002). Keunggulan sapi bali lainnya adalah tingkat kesuburan tinggi yaitu mencapai 80\% (Purwantara et al., 2012) walaupun berada pada kondisi pakan dalam jumlah dan kualitas yang rendah. Sapi bali dapat beradaptasi dan mempertahankan berat badan dengan baik pada kondisi iklim tropis (Thalib et al., 2002), dan persentase karkas yang tinggi dengan 
penyebaran lemak yang sedikit (Ngadiyono, 1997).

Produktivitas ternak sapi bali dalam beberapa tahun terakhir, mengalami penurunan. Angka kematian anak dapat mencapai 36-50\% (Jelantik, 2001), bobot lahir anak rendah yaitu berkisar antara17,33-18,00 kg (Suryani et al., 2017) dan tingkat pertumbuhan yang lamban yaitu 0,11-0,26 kg/ekor/hari (Marawali dan Ratnawaty, 2015). Penyebab utama rendahnya produktivitas sapi bali, salah satunya adalah rendahnya produksi susu induk yaitu 0,92 - 2,08 $\mathrm{kg} / \mathrm{ekor} / \mathrm{hari}$ (Sukarini et al., 2001) yang berdampak pada tidak terpenuhinya kebutuhan nutrisi anak setelah lahir dan mengakibatkan tingginya angka kematian dan lambannya tingkat pertumbuhan prasapih.

Kemampuan produksi susu induk sangat ditentukan oleh tingkat perkembangan kelenjar susu, yang secara fisiologis dikontrol hormon progesteron (Ruan et al., 2005; Lain et al., 2013; Rajaram et al., 2015). Penelitian sebelumnya telah menggunakan follicle stimulating hormone (FSH) dan luteonizing hormone (LH) sintetik untuk merangsang pertumbuhan kelenjar susu melalui rangsangan pembentukan corpus luteum sebagai penghasil hormon progesteron. Kedua hormon ini harganya sangat mahal dan tidak selalu tersedia pada saat dibutuhkan. Penelitian ini dirancang menggunakan ekstrak pituitari (EP) yang secara alami mengandung FSH dan LH (Kumar, 2007) untuk merangsang pertumbuhan kelenjar susu selama kebuntingan dan sekaligus sebagai penghasil hormon pertumbuhan yang dapat menunjang pertumbuhan anak sapi baik sebelum maupun setelah lahir (Edward, 2005).

Ekstrak pituitari telah banyak digunakan untuk superovulasi pada mencit (Hafizuddin et al., 2010; Kaka et al., 2018), ayam hutan merah (Piraksa dan Bebas, 2009), ikan lele dumbo (Jarigau, 1991), ikan mas (Oka, 1992; Syandry, 1992; Nalley, 1993) dan ikan komet (Andalusia et al., 2008). Ekstrak pituitari selain itu juga telah terbukti efektif untuk induksi estrus pada sapi (Isnaini dan Suyadi, 2004), dan meningkatkan kinerja reproduksi kambing lokal dan domba (Setiatin et al., 2008; Nalley dan Marawali, 2010; Siregar et al., 2013).

Informasi tentang pemanfaatan EP untuk meningkatkan produktivitas induk sapi bali bunting belum banyak dilaporkan, oleh karena itu penelitian ini bertujuan untuk menguji efektivitas pemberian EP terhadap produktivitas bunting sapi bali induk.

\section{METODE PENELITIAN}

\section{Koleksi dan Pengawetan Kelenjar Pituitari}

Hipofisis yang digunakan dalam penelitian ini berasal dari sapi bali yang dipotong di rumah potong hewan. Hipofisis dikoleksi segera setelah ternak dipotong, tengkorak kepala sapi dibelah, otak dikeluarkan, dan kelenjar pituitari yang tertinggal pada sella tursika diambil secara hatihati dan selanjutnya diawetkan secara kering yaitu dengan menggunakan aceton p.a (Susanto, 2001). Aseton diganti sebanyak tiga kali masing-masing selama delapan jam pada pergantian terakhir aseton dibiarkan selama 24 jam. Aseton setelah 24 jam dibuang dan selanjutnya diuapkan hingga kelenjar pituitari menjadi kering. Kelenjar pituitari yeng telah kering kemudian masukan ke dalam botol gelap selanjutnya di simpan pada suhu kamar $\left(28^{\circ} \mathrm{C}\right)$.

\section{Pembuatan Ekstrak Pituitari}

Pembuatan EP mengacu pada Nalley (1993), kelenjar pituitari yang kering digerus hingga menjadi tepung, selanjutnya tepung kelenjar pituitari ditimbang sesuai perlakuan, kemudian dilarutkan dengan aquabidest 20-75 $\mathrm{mL}$ hingga terlarut. Larutan kelenjar pituitari tersebut selanjutnya dimasukkan dalam tabung mikro dan disentrifuge dengan kecepatan 3000 rpm selama 15 menit. Supernatan (ekstrak pituitari) diambil dengan menggunakan micropipet, dan dimasukkan ke dalam tabung mikro dan disimpan pada suhu $-20{ }^{\circ} \mathrm{C}$ hingga saat digunakan.

\section{Penyuntikkan EP pada Induk Sapi Bali Bunting}

Sebanyak 12 ekor sapi bali bunting 2,5 bulan dibagi ke dalam empat perlakuan yaitu: tanpa injeksi EP (P0, kontrol), injeksi EP satu kali pada umur kebuntingan 2,5 bulan (P1), injeksi EP dua kali pada umur kebuntingan 2,5 dan 5,0 bulan (P2), dan injeksi EP tiga kali pada umur kebuntingan 2,5; 5,0 dan 7,5 bulan (P3). Dosis EP yang diberikan adalah $20 \mathrm{mg} / \mathrm{kg}$ bobot badan merupakan dosis terbaik hasil penelitian terdahulu (Nalley et al., 2017). Sapi-sapi tersebut diberi pakan berupa hijauan segar (lamtoro, rumput gajah, rumput kume, daun gamal, rumput lapangan), silase, hay sebanyak $10 \%$ dari berat badan dan konsentrat sebanyak $0,750 \mathrm{~kg} / \mathrm{ekor} / \mathrm{hari}$, hingga melahirkan.

Variabel penelitian adalah 1. Jumlah dan morfologi corpus luteum (CL) menggunakan 
metode palpasi per rektal, 2. Produksi susu induk diukur dengan cara pedet dipisahkan dengan induknya, susu diperah sebanyak dua kali sehari pada pagi dan sore hari, dan 3. Bobot lahir anak sapi. Data penelitian yang diperoleh dianalisis dengan uji sidik ragam dan dilanjutkan dengan Uji jarak berganda Duncan. Analisis menggunakan software SPSS 20.0 for windows.

\section{HASIL DAN PEMBAHASAN}

\section{Jumlah dan Ukuran Corpus Luteum}

Semua sapi menunjukkan adanya satu corpus luteum/CL, namun hanya satu ekor sapi yang menghasilkan dua CL $(2 / 12=0.17 \%)$. Panjang CL berkisar antara 0,22-0,38 cm, sedangkan lebar CL berkisar antara 0,18-0,30 $\mathrm{cm}$. Ukuran CL terbesar dihasilkan oleh sapi bali yang mendapat tiga kali injeksi EP (P3). Hasil analisis statistika menunjukkan tidak terdapat perbedaan pada jumlah dan ukuran CL $(\mathrm{P}>0,05)$ antar perlakuan (Tabel 1).

\section{Bobot Lahir Pedet}

Hasil penelitian menunjukkan bahwa bobot lahir pedet sapi cukup bervariasi. Bobot lahir pedet sapi bali yang tidak diberi EP (PO) dan diberi satu kali penyuntikan EP (P1) tidak berbeda dengan bobot lahir antara 12,53 $\pm 1,40$ $\mathrm{kg}$ sampai dengan $15,83 \pm 2,93 \mathrm{~kg}$. Keduanya lebih rendah $(\mathrm{P}<0,05)$ dibandingkan bobot lahir sapi bali yang diberi EP sebanyak dua dan tiga kali, dengan bobot lahir 17,87 $\pm 1,50 \mathrm{~kg}$ dan $19,87 \pm 1,72 \mathrm{~kg}$. Tidak terdapat perbedaan $(\mathrm{P}$ $>0.05$ ) bobot lahir antara P3 dan P4 (Tabel 2).

\section{Produksi Susu Induk}

Produksi susu diukur selama bulan pertama post-partum, menunjukkan bahwa produksi susu induk dipengaruhi oleh frekuensi injeksi EP. Produksi susu tertinggi $(1707,18 \pm 230,27$ $\mathrm{mL}$ ) dihasilkan oleh sapi-sapi yang diinjeksi tiga kali EP dan terendah $(1082,76 \pm 218,3 \mathrm{~mL})$ pada perlakuan kontrol $(\mathrm{P}<0,05)$. Tidak terdapat perbedaan produksi susu antara P3 dan P2 demikian juga antara P1 dan P2 (Tabel 2). Besaran peningkatan produksi susu pada sapi-

Tabel 1. Jumlah dan morfometri corpus luteum sapi bali yang diberi berbagai dosis ektrak pituitari sapi bali

\begin{tabular}{lcccc}
\hline \multirow{2}{*}{ Variabel } & \multicolumn{4}{c}{ Perlakuan } \\
\cline { 2 - 5 } & P0 & P1 & P2 & P3 \\
\hline Jumlah corpus luteum & $1,00 \pm 0,00$ & $1,00 \pm 0,00$ & $1,20 \pm 0,45$ & $1,00 \pm 0,00$ \\
Panjang (cm) & $0,22 \pm 0,04$ & $0,24 \pm 0,05$ & $0,40 \pm 0,14$ & $0,38 \pm 0,23$ \\
Lebar (cm) & $0,18 \pm 0,11$ & $0,26 \pm 0,05$ & $0,28 \pm 0,15$ & $0,30 \pm 0,07$ \\
\hline
\end{tabular}

Keterangan: tanpa injeksi EP (P0, kontrol), injeksi EP satu kali pada umur kebuntingan 2,5 bulan (P1), injeksi EP dua kali pada umur kebuntingan 2,5 dan 5,0 bulan (P2), dan injeksi EP tiga kali pada umur kebuntingan 2,5; 5,0; dan 7,5 bulan (P3).

Tabel 2. Bobot lahir dan produksi susu sapi bali yang diberi berbagai dosis ektrak hipofisis

\begin{tabular}{lcccr}
\hline Variable & \multicolumn{4}{c}{ Perlakuan } \\
\cline { 2 - 5 } & P0 & P1 & P2 & P3 \\
\hline Bobot lahir (kg) & $12,53 \pm 1,40^{\mathbf{c}}$ & $15,83 \pm 2,93^{\mathbf{c}}$ & $17,87 \pm 1,50^{\text {ab }}$ & $19,87 \pm 1,72^{\text {a }}$ \\
Produksi susu (mL) & $1082,76 \pm 218,3^{\mathbf{c}}$ & $1450,14 \pm 212,91^{\mathbf{b}}$ & $1608,23 \pm 217,24^{\text {ab }}$ & $1707,18 \pm 230,27^{\text {a }}$
\end{tabular}

Keterangan: Superskrip yang berbeda pada baris yang sama menunjukkan perbedaan yang nyata $(\mathrm{P}<0,05)$. Tanpa injeksi EP (P0, kontrol), injeksi EP satu kali pada umur kebuntingan 2,5 bulan (P1), injeksi EP dua kali pada umur kebuntingan 2,5 dan 5,0 bulan (P2), dan injeksi EP tiga kali pada umur kebuntingan 2,$5 ; 5,0$; dan 7,5 bulan (P3). 
sapi yang diinjeksi tiga kali EP mencapai 624,42 $\mathrm{mL}$ dibandingkan dengan kontrol.

Secara anatomis, kelenjar pituitari terletak tepat didasar otak yang biasanya tertinggal ketika otak diangkat. Kelenjar pituitari secara alamiah berfungsi sebagai penghasil berbagai hormon yang meregulasi fisiologis fungsi tubuh (Hafez, 2000). Kedudukan kelenjar pituitary ini di dalam tubuh sangatlah penting baik untuk menunjang pertumbuhan maupun untuk reproduksi. Beberapa hormon yang dihasilkan oleh kelenjar pituitari di antaranya adalah FSH, LH dan GH (Millar et al., 2004).

Hormon FSH bersama dengan LH juga berperan dalam pembentukan CL (Millar et al., 2004) yang selanjutnya CL ini akan menghasilkan hormon progesteron yang sangat penting untuk memelihara kebuntingan. Kadar progesteron akan meningkat dan berada dalam konsentrasi yang tinggi selama periode kebuntingan, karena salah satu peranan dari hormon ini adalah menciptakan lingkungan uterus yang dapat menunjang perkembangan fetus.

Progesteron juga sangat penting untuk menunjang perkembangan kelenjar susu (Conneely et al., 2002) selama masa kebuntingan sapi. Semakin banyak atau semakin besar CL yang terbentuk di ovarium, semakin banyak hormon progesteron yang dihasilkan dan selanjutnya berdampak pada perkembangan kelenjar susu yang optimal. Jumlah kelenjar susu yang terbentuk pada ambing selama masa kebuntingan berkorelasi positif dengan jumlah produksi susu yang dihasilkan oleh seekor induk sapi selama masa menyusui (Wang et al., 2009; Topal et al., 2010).

Penyuntikan EP pada ternak penelitian tidak memberikan respons yang berarti terhadap jumlah maupun morfometri CL, hal ini terlihat karena ovarium hanya mempunyai satu CL. Tidak adanya perbedaan antar perlakuan ini karena ternak sapi yang digunakan adalah sapi bali yang bunting alami dan tidak mengalami perlakuan hormon baik superovulasi ataupun sinkronisasi estrus. Hal ini mengindikasikan keseragaman penggunaan ternak penelitian. Hasil penelitian lain pada sapi yang mendapatkan perlakuan superovulasi menggunakan EP pada sapi aceh menghasilkan rata-rata empat CL (Arum et al. 2013), bahkan laporan Siregar et al. (2012) menghasilkan ratarata $5,4 \mathrm{CL}$

Secara fisiologis keberadaan CL di bawah pengaruh hormon LH dari adenohipofisis, CL terbentuk di ovarium bekas tempat ovum diovulasikan. Corpus luteum ini menghasilkan progesteron yang berperan secara aktif memelihara kebuntingan. Penggunaan EP untuk sapi bali yang sedang bunting secara alami mengandung FSH dan LH dimaksudkan untuk merangsang pertumbuhan anak yang dikandung dan pada saat yang bersamaan dapat meningkatkan produktivitas CL untuk menghasilkan hormon progesteron.

Hasil penelitian ini menunjukkan bahwa terjadi peningkatan produksi hormon progesteron terutama pada sapi bali yang diinjeksi tiga kali EP. Progesteron merupakan hormon dalam golongan steroid yang terlibat dalam siklus estrus, fertilisasi, dan merawat kebuntingan. Progesteron berperan besar dalam perkembangan fetus. Fungsi progesteron pada reproduksi ternak di antaranya mempertebal dinding endometrium setelah terjadi ovulasi, menghambat produksi LH agar CL mengalami degenerasi saat tidak terjadi fertilisasi, menghambat laktasi saat terjadi kebuntingan, dan mempersiapkan endometrium untuk implantasi zigot (Senger, 2003).

Pada Tabel 2 ditunjukkan adanya perbedaan bobot lahir antara 5,00-7,34 kg antara P0 dan P1 dengan P2 dan P3. Hal ini menunjukkan bahwa pemberian dua dan tiga kali injeksi EP pada induk sapi bali bunting dapat meningkatkan bobot lahir anak. Bobot lahir pedet sapi bali belakangan ini memang mengalami menurunan, hal ini dilaporkan oleh Thalib et al. (2002) bahwa bobot lahir hanya 11,9 $\mathrm{kg}$ atau 12,53 $\pm 1,40 \mathrm{~kg}$ (Martojo 2012) dengan kisaran 13-18 kg (Pane, 1990). Bobot lahir sapi bali bervariasi bergantung pola pemeliharaanya dan teknik breeding yang digunakan. Bobot lahir sapi bali sebenarnya dapat mencapai 25 $\mathrm{kg}$ dengan rerata $18,4 \mathrm{~kg}$ jika perkawinannya menggunakan teknik inseminasi buatan memanfaatkan straw dari pejantan hasil seleksi (Prasojo et al. 2010). Kaswati et al. (2013) melaporkan bobot lahir sapi bali 17,8 kg di Balai Pembibitan Ternak Unggul (BPTU) Sapi Bali di Pulukan, Jembrana, Bali. Induk sapi yang mendapatkan pakan rumput dan legume, semak dan pohon yang terjamin ketersediaan pakannya sepanjang tahun, memiliki bobot lahir anak dengan bobot $16,94 \mathrm{~kg}$, sedangkan ternak yang dipelihara secara tradisional memiliki bobot lahir hanya $15,62 \mathrm{~kg}$. Fenomena ini menunjukkan bahwa tampilan reproduksi sapi sangat bergantung dari status pakan yang diberikan. Pertumbuhan dan perkembangan 
fetus sangat dipengaruhi oleh faktor genetik (spesies, bangsa, ukuran tubuh dan genotip), faktor lingkungan (induk dan plasenta) serta faktor hormonal.

Penelitian ini juga menunjukkan bobot pedet yang dilahirkan oleh induk yang diberi injeksi EP sebanyak dua dan tiga kali, lebih berat dibandingkan dengan kontrol, hal ini karena dalam EP mengandung hormon pertumbuhan (growt hormone/GH). Hormon GH sangat penting dalam pertumbuhan dan membantu menjaga kondisi tubuh, sebagai penyeimbang distribusi lemak serta menjaga kesehatan tulang dan otot (Toelihere, 1985)

Berdasarkan hasil penelitian pemberian EP pada masa kebuntingan akan meningkatkan pertumbuhan embrio atau fetus yang selanjutnya terjadi peningkatan bobot anak yang dilahirkan. Bobot lahir merupakan salah satu faktor yang menentukan daya hidup dan pertumbuhan anak selanjutnya. Semakin tinggi bobot lahir anak, daya hidup dan pertumbuhan selanjutnya akan semakin tinggi, dan strategi ini dapat menekan angka kematian anak dan juga penting untuk pencapaian bobot dewasa pada umur yang lebih muda.

Produksi susu induk yang diberi berbagai dosis EP juga menunjukkan perbedaan. Induk yang diberi tiga kali injeksi EP, memproduksi susu lebih banyak dibandingkan dengan induk yang mendapat injeksi dua kali, satu kali atau kontrol. Hal ini diduga karena adanya kandungan prolaktin dalam EP yang menstimulasi produksi susu pada sapi induk. Semakin tinggi dosis EP yang diberikan diharapkan semakin tinggi produksi susu yang dihasilkan. Pemberian EP juga diharapkan dapat merangsang peningkatan jumlah produksi susu induk melalui perbaikan pertumbuhan kelenjar susu selama masa kebuntingan.

Hasil penelitian ini menunjukkan bahwa peningkatan frekuensi pemberian EP, memberikan respons yang meningkat pula terhadap produksi susu. Produksi susu dapat juga ditingkatkan dengan perbaikan kualitas pakan yang dikonsumsi dari $1,109 \mathrm{~kg} / \mathrm{hari}$ menjadi 2,229 kg/hari (Sukarini et al. 2010). Peningkatan produksi susu induk sapi bali yang ada NTT merupakan langkah strategis yang sangat penting mengingat sebagian besar kematian pedet (anak sapi) disebabkan oleh rendahnya produksi susu induk.

\section{SIMPULAN}

Pemberian ektrak pituitari tiga kali pada induk sapi bali bunting dapat meningkatkan bobot lahir anak dan produksi susu induk.

\section{UCAPAN TERIMA KASIH}

Penulis menyampaikan terima kasih kepada Dirjen Dikti yang telah memberikan bantuan dana melalui Penelitian Hibah Bersaing tahun 2019 dengan kontrak no. 70/ UN15.19/PL/2019.

\section{DAFTAR PUSTAKA}

Andalusia R, Mubarok AS, Damayanti Y. 2008. Respons pemberian ekstrak hipofisa ayam broiler terhadap waktu latensi, keberhasilan pembuahan dan penetasan pada pemijahan ikan komet (Carassius auratus aurataus). Berkala Ilmiah Perikanan 3(1): 21-27

Arum WP, Siregar TN, Melia J. 2013. Efek pemberian ekstrak hipofisa sapi terhadap respons superovulasi sapi Aceh. Jurnal Medica Veterinaria 7(2): 71-74

Conneely OM, Mulac-Jericevic B, DeMayo F, Lydon JP and O'Malley BW. 2002. Reproductive functions of progesterone receptors. Recent Progress in Hormone Research 57: 339-355.

Dahlanuddin D, Supriyadi M, PanjaitanTS, Poppi DP, Quigley SP. 2016. Increased body condition lactase increases milk production and pre-weaning growth of bali cattle. Jurnal of Animal Science 94(5): 399-400

Edward DP. 2005. Regulation of signal transduction pathways by estrogen and progesterone. Annual Review of Physiology 67: $335-376$.

Food and Agriculture Organization (FAO). 2012. Conserving and developing farm animal diversity. Roma: Secretariat of the report on the state of the word's Animal genetic resources. Ruma. FAO Roma.

Hafez ESE,Hafez B. 2000. Reproduction in Farm Animals. $7^{\text {th }}$ ed. Philadelphia, USA. Lea and Febiger. 
Hafizuddin, Suryani, Yusmadi, Siregar TN, Armansyah T. 2010. Respons superovulasi mencit dengan ekstrak hipofisa: Suatu upaya menemukan agen superovulasi dengan biaya murah. Prosseding Seminar nasional berkelanjutan. Fakultas Peternakan Universitas Padjajaran.

Isnaini N, Suyadi. 2004. Pengaruh system pemberian ekstrak hipofisa terhadap respons berahi dan respon ovary sapi perah anestrus postpartum. Jurnal Ilmu-ilmu Hayati 16(1): 33-40

Jarigau. 1991. Ekstrak hipofisa ayam petelur sebagai bahan perangsang ovulasi pada ikan lele dumbo (Clarias geriepinus) [Thesis]. Bogor. Institut Pertanian Bogor.

Jelantik IGN. 2001. Improving bali cattle (Bibos banteng) production through protein suplementation. (PhD. Thesis). Copenhagen. The Royal Veterinary and Agricultural University.

Kaka A, WM Nalley, Hine TM. 2018. Efek Ekstrak Hipofisa Sapi terhadap Pertambahan Bobot dan Umur Pubertas Mencit Betina (Mus musculus). Jurnal Peternakan Indonesia 20(2): 91-98

Kaswati, Sumadi, Ngadiyono N. 2013. Estimasi nilai heritabilitas berat lahir, sapih, dan umur satu tahun pada sapi bali di Balai Pembibitan Ternak Unggul Sapi Bali. Buletin Peternakan 37(2): 74-78.

Kumar TR. 2007. Multiple ovulations, ovarian epithelial inclusion cysts, and It'SMAD two! Endocrinology 148: 3591-3594.

Lain AR, Creighton CJ, Conneely, OM. 2013. Research Resource: progesterone receptor targetome underlying mammary gland branching morphogenesis. Mol Endocrinol 27(10): 1743-1761.

Marawali HH, Ratnawaty S. 2015. The Effect of Timor Island Legumes on Body Weight Gain of Post Weaning Bali Cattles. Journal of Agricultural Science and Technology A 5: 203-209.

Martojo H. 2012. Indigeneus Bali cattle is most suitable for sustainable small farming in Indonesia. Reprod Dom Anim 47(1): 10-14

Millar RP, Lu Z-L, Pawson AJ, Flanagan CA, Morgan K, Maudsley SR. 2004. Gonadotropin-releasing hormone receptors. Endocrine Reviews 25: 235-275.
Nalley WM. 1993. Perbandingan penggunaan ekstrak hipofisa hipothalamus bagian dorsal dan bagian ventral babi terhadap spermiasi dan daya tetas telur ikan mas (Cyprianus carpio L) (Thesis). Bogor. Institut Pertanian Bogor.

Nalley WM, Warawali A. 2010. Penggunaan ekstrak hipofisa dalam rangka meningkatkan angka ovulasi pada kambing peranakan etawah. Kupang. Fakultas Peternakan. Universitas Nusa Cendana.

Nalley WM, Kune P, Hine MT. 2017. Tampilan estrus dan angka kebuntingan sapi bali pasca pemberian ekstrak pituitary. Jurnal Acta Veterinaria Indonesiana 5(2): 75-79.

Oka AA. 1992. Studi anatomi perbandingan letak kelenjar hipofisa ternak sapi, kerbau dan domba serta pengaruh ekstraknya terhadap spermiasi dan mani ikan mas (Cyprinuscarpio L). (Thesis). Bogor. Institut Pertanian Bogor.

Pane I. 1990. Upaya peningkatan mutu genetic sapi bali di P3 Bali. Pross Seminar nasional Sapi Bali. Bali 20-22 September 1990.

Piraksa IW, Bebas W. 2009. Pengaruh penyuntikan ekstrak hipofisa terhadap berat testes, gambaran mikroskopis testes dan kualitas semen ayam hutan merah (Gallus gallus). Buletin Veteriner Udayana 1(1): 13-19.

Purwantara B, Noor RR, Andersson G, Rodríguez-Martínez H. 2012. Banteng and Bali Cattle in Indonesia: Status and Forecasts. Reproduction in Domestic Animals 47(1): 2-6.

Prasojo G, I Arifiantini, K Mohamad. 2010. Korelasi antara lama kebuntingan, Bobot lahir dan jenis kelamin pedet hasil inseminasi buatan pada sap Bali. Jurnal Veteriner 11(1): 41-45

Rajaram UD, Buric D, Caikovski M, Ayyanan A, Rougemont J, Shan J, Vainio SJ, YalcinOzuysal O, Brisken C. 2015. Progesterone and Wnt4 control mammary stem cells via myoepithelial crosstalk. The Embo Journal 34(5): 641-652.

Ruan W, Monaco ME, Kleinberg DL. 2005. Progesterone stimulates mammary gland ductal morphogenesis by synergizing with and enhancing. insulin-like growth factor-I action. Endocrinology 146(3): 1170-1178. 
Senger PL. 2003. Pathways to pregnancy and parturition. Washington state University Research \& Tehnology Park $2^{\text {nd }}$. Washington. Current Conceotion Inc.

Setiatin SET, Kuncara S, Mayasari. 2008. Pengaruh pemberian ekstrak hipofisa terahadap estrus dan fertilitas domba selama kebuntingan sebagai prediktor untuk menunjang keberhasilan reproduksi; prediksi jumlah anak, bobot lahir, pertumbuhan kelenjar susu dan produksi susu. Seminar Nasional Peternakan. Ciawi Bogor. 20-21 November 1997.

Siregar TN, Siregar IK, Armansyah T, Syafruddin, Arman Sayuti, Hamdani. 2013. Tampilan reproduksi kambing local hasil induksi superovulasi dengan ekstrak pituitary. Jurnal Veteriner 14(1): 75-79.

Siregar TN, Eldora MG, Melia J, Panjaitan B, Yusmadi, Barus RA. 2012. Kehadiran folikel dominan pada saat inisiasi superovulasi menurunkan respons superovulasi sapi Aceh. Jurnal kedokteran Hewan 6(2): 67 71

Sukarini IAM, Sastradipradja D, Nusada N, Mahardika IG, Kiranadi B. 2001. Mammary performance of first lactation bali cows (Bibos banteng) fed grass- legume based diets in relation to the role of glucose. AsianAust J Anim Sci 14(5): 615-623).

Sukarini IAM, Putra S, Mahardika IG, Suriasih K, Hartawan M. 2010. Milk production of Bali cows (Bibos banteng) given konsentrate supplementation of grass-legunie based at early lactation. Proceedings Seminar Internatinal Conservation and improvement of world indigenous cattle. Study Center For Bali Cattle Udayan University Bali.
Suryani NN, Suarna IW, Sarini NP, Mahardika IG, Duarsa MNP. 2017. Pemberian ransum berenergi tinggi memperbaiki performans induk dan menambah bobot lahir pedet sapi bali. Jurnal Veteriner 18(1): 154-159.

Susanto H. 2001. Teknik Kawin Suntik Ikan Ekonomis. Jakarta. Penebar Swadaya.

Syandry H. 1992. Dosis optimal ekstrak hipofisa sapi untuk menghasilkan mani dan daya tetas telur ikan mas (Cyprinus carpio L). (Thesis). Bogor. Institut Pertanian Bogor

Talib C, Entwistle K, Siregar A, Budiarti-Turner S, Lindsay D. 2002. Survey of Population and Production Dynamics of Bali Cattle and Existing Breeding Programs in Indonesia. Proceedings of an ACIAR workshop on Strategies to improve Bali cattle in Eastern Indonesia, Denpasar Bali.

Toelihere MR. 1985. Inseminasi Buatan pada Ternak. Bandung.Penerbit Angkasa.

Topal M, Aksakal V, Bayram B, Yaðanoðlu AM. 2010. An analysis of the factors affecting birth weight and actual milk yield in Swedish red cattle using regression tree analysis. The Journal of Animal \& Plant Sciences 20(2): 63-69.

Wang XZ, Brown MA, Gao FQ, Wu JP, Lalman DL, Liu WJ. 2009. Relationships of milk production of beef cows to postweaning gain of the calves. The Professional Animal Scientist 25: 266-272. 